\title{
Call for Proposals of Articles for a Special Issue of Public Organization Review (POR) on Public Sector Accountability and Corruption Problems SI \#4
}

\author{
Ali Farazmand ${ }^{1} \cdot$ Yanzhe Zhang $^{2} \cdot$ Christopher L. Atkinson $^{3}$
}

Published online: 24 July 2021

( ) Springer Science+Business Media, LLC, part of Springer Nature 2021

\section{Background}

Corruption and fraud in administration of the public sector represents a clear, present danger, not only through the misuse of increasingly scarce public resources, but also in the long-term potential for damage to confidence in public institutions, resulting in a disaffected, distrustful citizenry. Problems like this are not unique to any particular nation, and public sector corruption manifests in a variety of ways (Lennerfors, 2009). Certain areas of the public sector enterprise, such as public procurement and public-private partnerships (Bildfell, 2018), are of particular concern for corruption. Transparency has been called a problem and a solution across the whole of public administration (Pozen, 2019). Accountability is called for; instrumental approaches and simple provision of information, and systems shot-through with exceptions, undermine accountability from the public's perspective (Mabillard \& Zumofen, 2020). Restrictions and exclusions call into question the reality of public accessibility for government contracting opportunities, but also raise larger implications for the prevalence of waste (Plaček et al., 2020). Professional failures in public administration can prevent attainment of public value (McCue et al., 2018).

Public Organization Review welcomes articles for an upcoming special issue of on public sector accountability and corruption, with special emphasis on public procurement and public-private partnerships. International scholars are welcome to bring their empirically-led analyses to bear on these important topics. It

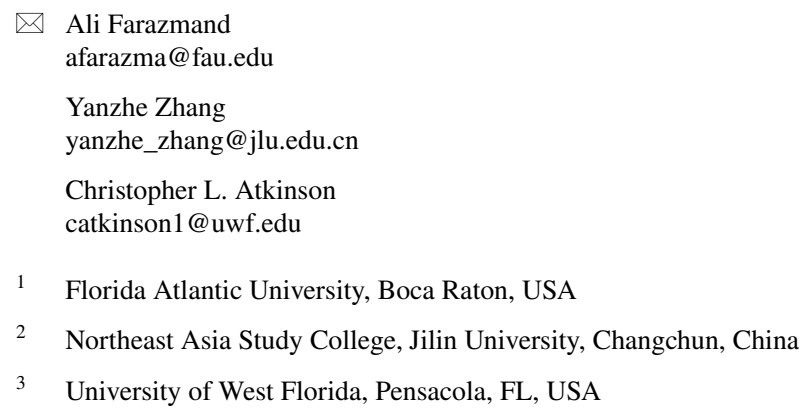


is hoped that the resulting issue will be responsive not only to filling gaps in the literature, but also to assisting in improvements to the public sector by posing not only problems, but solutions for today's challenging public environment.

Public purchasing is often characterized by an intricate system of processes and rules, challenging to well-seasoned government vendors, but also serving as a barrier for many vendors that could potentially be interested in providing products and services to government. The playing field for seeking and winning government contracts is not level, in this respect, and the pleadings of government officials to gather more bidders, to heighten competition, frequently come to naught. In the resultant exclusive environment, the sense of duty and obligation among public servants have often made the difference. However, challenging circumstances, including COVID-19's impact on public sector processes, have exposed vulnerabilities, including tendencies toward mismangement and misue of resources (Teremetskyi et al., 2021). This demonstrates a need for additional attention in the literature, as corruption can turn hazards into disasters (Escaleras \& Register, 2016).

In addition to victims in the business sector, possibly sidelined from participation by cozy relationships between incumbant vendors and public officials (Atkinson et al., 2020), and tendencies toward repeat contracting (Plaček et al., 2020), corruption has real financial implications, in increased cost and inefficiency in processes. Even where extensive efforts have been made to address and combat corruption, instances of corruption nevertheless persist (Saddiq \& Kessa, 2020). These systems can be undermined by staffing issues, a derth of public participation, and lack of follow-through on identified problems, among other concerns (Prateeppornnarong, 2021). Perception of corruption is rampant, but misunderstanding about its prevalence is spurred by curtailment of press freedom (Flavin \& Montgomery, 2020); there is an opportunity to bring in the public, rather than exclude, but how has this been successfully engaged in practice?

Extending beyond the practical implications of corruption for government entities, and how even isolated instances of corruption can be damaging to the broad enterprise of public work, academic literature has had, and will continue to have, a role in identifying problems, fashioning responses, and seeking a way forward for more accountable public services.

\section{Examples of Suitable Topics for the Special Issue}

Empirical analyses of corruption, and tendencies toward inefficiency and waste, in public-private partnerships.

Inquiries into public sector corruption, especially data-driven examinations of public procurement processes, rules and frameworks, and outcomes.

Studies of cost-overruns on public sector projects (Sarmento \& Renneboog, 2017).

The connection between public sector practices and processes, and the reality or perception of public sector corruption, using replicable analytic processes. 


\section{Proposals and Manuscripts}

Proposals should clearly present: (1) a descriptive title; (2) a statement of theme and purpose that includes a problem statement; (3) research questions, including descriptive and explanatory parts; (4) a theoretical/literature base, briefly outlining central theories and concepts; (5) the 'originality' and significance of the paper; (6) a brief methodology statement that includes, for example, sources of data and tools and methods; and (7) the paper's added value including potential contributions to knowledge (generalizability). Proposals should not exceed the 2-page limit. Please indicate: "For SI \# 4."

Completed manuscripts should not exceed 30 pages double spaced (or 8000 words), inclusive of all tables, figures, and charts. APA style with third person writing is required. Style guidelines are on the POR website.

\section{Timetable to Publication}

Interested scholars are invited to submit proposals of approximately 800 to 1000 words POR by October 30, 2021. Proposing authors will be notified by November 15, 2021.

Draft manuscripts of accepted proposals are due by December 31, 2021.

Authors of draft manuscripts will receive a preliminary review by January 30, 2022 from the Guest Editors; they will include:

(1) A recommendation to complete the manuscript likely with some suggested revisions;

(2) A recommendation to revise and resubmit with more substantive revisions; or

(3) A decision that the manuscript will not be accepted - consider submitting it to a different journal. A review with a (1) or (2) recommendation does not guarantee acceptance of the final manuscript.

Final manuscripts are due March 15, 2022. Final manuscripts will be doubleblind reviewed during March and April 2022.

Final reviews and decisions will be posted on POR's Editorial Manager's Site by May 30, 2022.

The Special Issue will be published in POR: Online June-July 2022 and in print, in late 2022.

Proposals and manuscripts should be submitted to the Editor-in-Chief of POR, or any of the Guest editors-see below.

Questions about the substance or process for proposals, manuscripts, or the Special Issue should be submitted to a Guest Editor.

Charis Atkinson, University of West Florida, USA, Emal: catkinson@uwf.edu

Yanzhe Zhang, Jili University, China, Email: yanzhe_zhang@jlu.edu.cn 


\section{References}

Atkinson, C. L., McCue, C., Prier, E., \& Atkinson, A. M. (2020). Supply chain manipulation, misrepresentation, and magical thinking during the covid-19 pandemic. American Review of Public Administration, 50(6-7), 628-634.

Bildfell, C. (2018). P3 infrastructure projects: A recipe for corruption or an antidote? Public Works Management \& Policy, 23(1), 34-57.

Escaleras, M., \& Register, C. (2016). Public sector corruption and natural hazards. Public Finance Review, 44(6), 746-768.

Flavin, P., \& Montgomery, F. (2020). Freedom of the press and perceptions about government corruption. International Political Science Review, 41(4), 554-566.

Lennerfors, T. T. (2009). The vicissitudes of corruption: Degeneration, transgression, jouissance. Business \& Society, 48(3), 406-419.

Mabillard, V., Zumofen, R. (2020). Transparency and accountability - The Case of Public Procurement Practices in Switzerland Public Works Management \& Policy, in Press 1-20 https://doi.org/10.1177/ $1087724 X 19898699$

McCue, C. P., Prier, E., \& Steinfeld, J. M. (2018). Establishing the foundational elements of a public procurement body of knowledge. Journal of Strategic Contracting \& Negotiation, 4(4), 233-251.

Plaček, M., Soukopová, J., Vaceková, G., Ochrana, F., \& Schmidt, M. (2020). Another one bites the dust: Recurrent procurement contracts in the Czech Republic. Public Works Management \& Policy, 25(4), $365-385$.

Pozen, D. E. (2019). Seeing transparency more clearly. Public Administration Review, 80(2), 326-331.

Prateeppornnarong, D. (2021). Fighting corruption while having hands tied: A case study of Thailand's public sector anti-corruption commission. Journal of Asian African Studies, 56(2), 320-334.

Sadiq, A., \& Kessa, R. (2020). U. S. procurement in the age of covid-19: Challenges, intergovernmental collaboration, and recommendations for improvement. American Review of Public Administration, 50(6-7), 635-641.

Sarmento, J. M., \& Renneboog, L. (2017). Cost overruns in public sector investment projects. Public Works Management \& Policy, 22(2), 140-164.

Teremetskyi, V., Duliba, Y., Kroitor, V., Korchak, N., \& Makarenko, O. (2021). Corruption and strengthening anti-corruption efforts in healthcare during the pandemic of covid-19. Medico-Legal Journal, $89(1), 25-28$.

Publisher's Note Springer Nature remains neutral with regard to jurisdictional claims in published maps and institutional affiliations. 